\begin{tabular}{|c|l|}
\hline Title & Kin-related Social Organization in a Winter Population of the Vole Clethrionomys rufocanus \\
\hline Author(s) & Ishibashi, Y asuyuki; Saitoh, Takashi; A be, Syuiti; Y oshida, Michihiro C. \\
\hline Citation & Researches on population ecology, 40(1), 51-59 \\
\hline Issue Date & 1998 \\
\hline Doc URL & http://hdl.handle.net/2115/16998 \\
\hline Type & article \\
\hline File Information & RPE40-1-51.pdf \\
\hline
\end{tabular}

Instructions for use 


\title{
Kin-related Social Organization in a Winter Population of the Vole Clethrionomys rufocanus
}

\author{
Yasuyuki IshiBASHI $\left.{ }^{*}, 1\right)$, Takashi SaitoH ${ }^{\dagger, 2)}$, Syuiti ABE* and Michihiro C. YoshidA* \\ ${ }^{*}$ Chromosome Research Unit, Faculty of Science, Hokkaido University, North 10, West 8, Sapporo 060-0810, Japan \\ ${ }^{\dagger}$ Hokkaido Research Center, Forestry and Forest Products Research Institute, Sapporo 062-8516, Japan
}

\begin{abstract}
Kinship among Clethrionomys rufocanus was investigated during the winter of 1992/93 in a 3-ha enclosure using both molecular and catch-mark-release techniques. Forty-six adult voles (22 males and 24 females) having high heterozygosities, which were collected from several natural populations, were released into the enclosure on 29 September 1992. Most fall-born individuals of both sexes stayed in their natal site during the non-breeding period (December-March), although reproductively active females dispersed during the fall breeding season (October-November). These philopatric individuals aggregated and formed an maternal family in the winter. Several females which failed to reproduce were solitary during this season. Some individuals which were derived from several families also aggregated into a mixed lineage group. Survival rate of fall-born voles from earlier litters was higher than that from later ones. Maternal families broke up soon after the onset of spring reproduction. Most females established a territory near the wintering site and made a kincluster, in which close relatives neighbored each other. Maternal families in winter bring about female kin-clusters in spring, which may influence reproductive output in the breeding season.
\end{abstract}

Key words: communal nesting, kinship, microsatellite DNA, parentage.

\section{Introduction}

Populations of the vole Clethrionomys rufocanus (Sundevall, 1846) exhibit both periodic and aperiodic density fluctuations in Hokkaido, Japan (Bjørnstad et al. 1996, 1998; Stenseth et al. 1996; Saitoh et al. 1998b). Both patterns of fluctuations are based on a seasonal change in abundance; populations usually increase from spring to fall (Saitoh 1987; Saitoh et al. 1998a). Although fall abundance varies greatly from year-to-year, abundance is less variable in spring (Saitoh 1987; Saitoh et al. 1998a). This implies that both rates of winter decline and summer increase differ among years (see also Yoccoz et al. 1998). The density-dependent process during the winter may be particularly important (Stenseth et al. 1998). Population structure (not abundance) in spring, being influenced by winter social organization, may affect the change in abundance in the subsequent season. The degree of relatedness among neighbors may be one of the keys to understand the demographic processes from spring (Lambin and Krebs

1)E-mail: stone@ees.hokudai.ac.jp

2)E-mail: bedford@ffpri-hkd.affrc.go.jp
1991). Vole populations with low relatedness may be subject to a severe spring decline due to exclusiveness, and would therefore not reach high densities during that year, whereas populations with high relatedness may maintain a relative high density during spring due to mutual tolerance and would build to peak numbers. In contrast, there are no clear hypotheses for explaining the winter decline.

Huddling, or communal nesting, during winter is widely known in microtine rodents (see Madison 1984; West and Dublin 1984; Wolff 1985). Kin structure is rarely reported among members within a shared nest, except for a few studies in Microtus. In an enclosed population of meadow voles ( $M$. pennsylvanicus), a mother, juveniles and one or more adult males nested communally from fall to early winter. When group sizes decreased by predation, these voles changed groups and formed a mixed lineage group (Madison et al. 1984; Madison and McShea 1987). In the taiga vole ( $M$. xanthognathus), members of overwintering groups were not always close relatives although female litter mates occasionally join the same group (Wolff and Lidicker 1981; see also McGuire and Getz 1995 for $M$. ochrogaster).

Because of female philopatry, female kin clusters will be 
formed in spring (Boonstra et al. 1987; Salvioni and Lidicker 1995; Ishibashi et al. 1997, 1998). Such a cluster may positively affect reproductive success owing to altruistic and cooperative sharing of space and other resources (Kawata 1987; Lambin and Krebs 1993; Mappes et al. 1995; but see also Sera and Gaines 1994). Maintained familiarity among relatives may function to avoid inbreeding during the following spring (see Getz et al. 1993). Furthermore, continuous contact will generate familiarity among unrelated individuals, and this may also affect the spatial distribution, reproductive success and/or survival of individuals in the following spring (Ylönen et al. 1990, 1995; see also Wolff 1995).

Winter communal nesting is known in the gray-sided vole (Clethrionomys rufocanus) (Kalela 1957; Saitoh 1989). Kinship among nest-sharing individuals is essentially unknown, although it is implied among them (Saitoh 1989). In the present study, using microsatellite DNA markers, kinship among spatially associating gray-sided voles was investigate from fall to early spring within a large outdoor enclosure. Describing a winter social organization based on relatedness will provide background information to make a hypothesis for explaining the winter decline and to understand the spring-fall processes.

\section{Materials and methods}

\section{Study site}

This study was conducted within a 3-ha outdoor enclosure $(200 \times 150 \mathrm{~m})$ in a natural broad-leaved forest $\left(42^{\circ} 59^{\prime} \mathrm{N}\right.$, $\left.141^{\circ} 23^{\prime} \mathrm{E}\right)$ in Hokkaido, the northernmost island of Japan. The enclosure was fenced with iron sheets extending about $1.3 \mathrm{~m}$ above ground and about $0.5 \mathrm{~m}$ underground to prevent both emigration and immigration of voles. The forest consisted mainly of birch, Betula platyphylla, and oak, Quercus mongolica var. grosseserrata. The undergrowth inside the enclosure was dominated by two species of dwarf bamboo, Sasa kurilensis and $S$. senanensis, occupying $38 \%$ and $62 \%$ of the area, respectively. Gray-sided voles eat leaves and shoots of these bamboo grasses during winter. An open 5-m wide area split the enclosure into two. It seemed that this area did not prevent movement of voles, although home ranges rarely crossed it.

Snow covered the ground from 12 December 1992, maximum snow depth $(88 \mathrm{~cm})$ was recorded on 19 February 1993, and melted away by 9 April. We defined here winter as the period from December to March. Monthly average temperatures during this period (DecemberMarch) were as follows: $-1.6^{\circ} \mathrm{C},-3.4^{\circ} \mathrm{C},-3.9^{\circ} \mathrm{C}$, and $-0.5^{\circ} \mathrm{C}$. These data were obtained at the meteorological station of Hokkaido Research Center, Forestry and Forest
Products Research Institute, about $2 \mathrm{~km}$ apart from the enclosure.

\section{Founders}

Forty-six, unrelated gray-sided voles ( 22 males and $24 \mathrm{fe}-$ males) were released into the enclosure on 29 September 1992. They were collected at several locations in the Ishikari Plain, neighboring Sapporo, from May to early September of 1992 and selected to maximize heterozygosities at three microsatellite loci, MSCRBs-2, -3, and -5 (DDBJ/EMBL/GenBank D37833, D37834, and D37836; Ishibashi et al. 1995) so as to facilitate the determination of parentage for each of the juveniles captured within the enclosure. Before releasing them, the enclosure was trapped intensively to remove voles already living there (and coming from an earlier experiment in the enclosure). Nevertheless, two fall-born voles (i.e. one male and one female) were captured after releasing the experimented voles. The fall-born male was removed from the enclosure, whereas the female was left as one of the founders since she had already mated with an introduced male before being detected (through trapping). Thus, the enclosed population was in effect started with 47 individuals. The average body weights of these founders were $28.1 \mathrm{~g}$ $(\mathrm{SD}=5.67$, range $=17.5-42 \mathrm{~g}$ ) for females and $34.6 \mathrm{~g}$ $(\mathrm{SD}=8.27$, range $=20-48 \mathrm{~g})$ for males at the time of release.

\section{Trapping regimes}

Two different trapping regimes were employed to monitor demography and social organization of the gray-sided vole within the enclosure: (1) grid trapping at 300 trap stations with 10-m interval, each of which having two traps, and (2) supplemental trapping to capture weanlings as early as possible after weaning, using several traps within the mother's range. Sherman-type live traps baited with oats were used and a handful of cotton was supplied to each of the traps for bedding. Each trap station was covered with a wooden box to keep traps sheltered from rain and snow. Grid trapping was carried out biweekly for three days from mid-October of 1992 to mid-January of 1993, and from late March to May of 1993. Heavy snow prevented us from trapping during late January to mid-March. Traps were set at $0900 \mathrm{~h}$ and checked twice at $1400 \mathrm{~h}$ and $2000 \mathrm{~h}$; all traps were closed after checking at $2000 \mathrm{~h}$. Supplemental trapping was conducted throughout the breeding season (October-November), in which traps were set at $0900 \mathrm{~h}$ and checked and closed at $1400 \mathrm{~h}$.

All voles were identified by toe-clipping at the first capture (maximum one toe per foot) and clipped toes were collected to extract genomic DNA (see below). Location, identity, sex, weight (once or more per trapping session) 
and reproductive status were recorded at each capture. Males were classified as reproductively inactive when testes were abdominal, and active when testes were scrotal. Females were classified as reproductively inactive if the vulva was closed, and active if the vulva was open, or whether they were pregnant or lactating. When a pregnant female was captured, the growth stage of fetus was assessed by palpation. Based on the palpation, the reproductive status of mother and the first appearance date of weanlings, the parturition date was estimated for all litters.

\section{Determination of parentage}

Genomic DNA was extracted from clipped toes using a conventional phenol/chloroform method (Sambrook et al. 1989), and genotypes were determined with the polymerase chain reaction (PCR) technique at three highly variable microsatellite loci (MSCRBs-1, -2 and -4; DDBJ/ EMBL/GenBank D37832, D37833 and D37835) after Ishibashi et al. (1995). For amplifying the locus MSCRB-2, we used a new oligonucleotide PCR primer, 5'-TCTCAGATTCTGTGATATGCTGTC-3', rather than the previously reported one, 5'-CCATTAAATGTTCTCAGGGA-3' (Ishibashi et al. 1995), in order to reduce the size of amplified products. In the 47 founders, 13,25 and 13 alleles were scored at the loci MSCRBs-1, -2 and -4 , respectively.

Parentage was established for all captured juveniles as follows: (1) candidates of the mother of a juvenile were nominated based on their reproduction career (the time of pregnancy and lactation) and the location of their home ranges (overlapping or adjoining with the juvenile's), and the mother was determined on the basis of genotypes at the three microsatellite loci, (2) paternally transmitted microsatellite alleles were determined for each litter by comparing the mother's genotypes with that of its offspring's, and (3) the male having all the paternal alleles was determined as the father of the litter.

Here, based on the kinship, we defined two social organizations. (i) The maternal family: a group consisting of maternal relatives (mother and sibling or sibling having the same mother) having overlapping or adjoining home ranges. (ii) The kin cluster: individuals with high relatedness establishing an independent home range in proximity.

\section{Social behavior}

Home ranges were estimated by minimum boundary range method (Stickel 1954). The center of activity was calculated as the arithmetic mean point of each individual's capture coordinates (Hayne 1949). The center of activity of a mother around parturition date was defined as the natal site of her offspring. Minimum straight line distance from the natal site to the center of activity at the beginning of overwintering (mid-January of 1993) was used as the indicator of movement distance. Movement distance from the natal site with longer than twice the average home range length (Stickel 1954) was used as the critical value of dispersal events; i.e. young that moved more than $50 \mathrm{~m}$ were defined as a disperser (see below). All statistical analyses were performed using SPSS (SPSS 1995); Monte Carlo based significance was calculated for the MannWhitney $U$-test and the Chi-square test to obtain exact $P$ value.

\section{Results}

\section{Population change}

Founders began to breed just after the release, and continued to do so until November of 1992. Of 25 female founders, 17 held an exclusive home range (i.e. territory), and became pregnant once or more during the fall. A total of 144 weaned juveniles ( 78 males and 66 females) were captured during the 1992 -fall breeding season. Three fall-born females also became pregnant once during this breeding season, and one of them weaned two young. At the first capture, most weaned juveniles ( $n=121,84 \%)$ weighed less than $20 \mathrm{~g}$, and only five (four females and one male) weighed over $20 \mathrm{~g}$ and were reproductively active.

At mid-January 1993, 124 voles were alive under snow cover ( 7 male and 13 female founders and fall-born 56 males and 48 females). The population decreased to 51 (founders; 3 male and 2 female, fall-born; 20 males and 26 females) by early April. Sex ratio ([number of males]/[population size]) decreased slightly from 0.51 to 0.45 during the population decline. Winter breeding was not observed. Reproductive activities resumed in late March in spite of the presence of snow, and the first weaned juveniles were captured in late April. One fallborn male and one male founder accidentally died in traps (both of which were excluded from analyses).

\section{Parentage}

Parentage was established unequivocally by genotyping at three microsatellite loci for all weaned juveniles captured during the fall breeding season $(n=144)$. Seventeen female founders and one fall-born female mothered them ( 32 litters, average number of weaned juveniles per litter 4.5 , $\mathrm{SD}=1.61$, range $=1-8$ ), in which 12 founders reproduced twice successfully and one founder three times. The average number of weaned offspring for the 18 mothers was $8.0(\mathrm{SD}=3.31$; range $=2-12)$. Twelve male founders sired the litters, and the average number of sired offspring was 12.0 for these males $(\mathrm{SD}=9.65$; range $=2-33$ ). Multiple paternity was found in two litters, each of which was sired by two male founders. 


\section{Dispersal}

In mid-January (11-13 January) of 1993, the average home range length did not differ between the sexes (males $24.1 \mathrm{~m}, \mathrm{SD}=10.66, n=63$; females $22.06 \mathrm{~m}, \mathrm{SD}=12.06$, $n=60$; Mann-Whitney $U$-test, $Z=-1.019, P=0.307$ ). More than $80 \%$ of fall-born voles $(85 / 104)$ located within $50 \mathrm{~m}$ from their natal site (Fig. 1). Although male graysided voles are known to disperse further than females on average (Ims 1989; Saitoh 1995), the average natal movement distance for females was to some extent greater than that for males in the fall (males $28.9 \mathrm{~m}, \mathrm{SD}=36.39, n=56$; females $38.0 \mathrm{~m}, \mathrm{SD}=38.78, n=48$ ), but the difference was not significant (Mann-Whitney $U$-test, $Z=-1.88$, $P=0.063$ ).

Dispersal was related to the onset of reproduction in females in fall. Most dispersing females moved from their

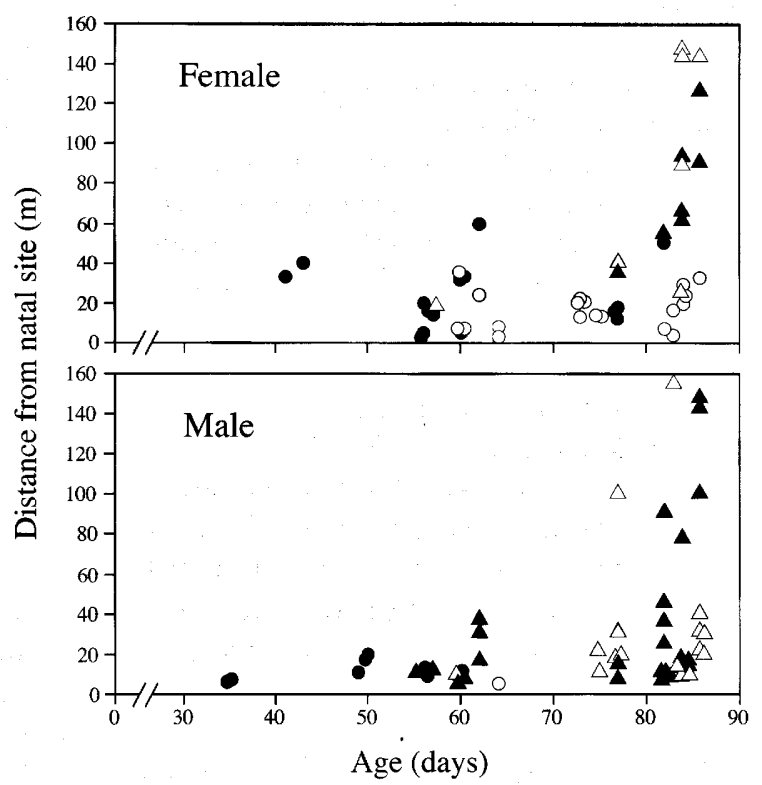

Fig. 1. Relationship between age (days) and distance from the natal site (m) at mid-January 1993. Triangles represent individuals which became reproductively active by mid-January 1993 . Open symbols are voles which survived the winter. Closed symbols are voles which died during the winter. natal site at 30-40 days old, and became reproductively active, whereas a very few of philopatric young females, which located within $50 \mathrm{~m}$ from their natal site, became reproductively active during the fall (Fig. 1). Proportion of mature females was significantly higher in dispersers than in philopatric voles $(10 / 11$ for dispersers, $3 / 21$ for philopatric females; Fisher's exact test, $P<0.001)$. Three of 13 fall-born females that matured during that fall, became pregnant during the fall. Dispersing young males left around 30-50 days old, and most of them settled in proximity to a reproductively active, unrelated fall-born female in the breeding season. Most fall-born males appeared to be reproductively active regardless of the distance from their mother (Fig. 1); proportion of mature males was similar between in dispersers and in philopatric voles ( $7 / 7$ for dispersers, $27 / 33$ for philopatric females; Fisher's exact test, $P=0.289$ ). No fall-born males, however, succeeded to sire during the fall breeding season.

Among 11 maternal families with two or more litters at mid-January, young from the second or third litters located closer to their natal site than those from the first litters (for the first litter young, mean $48.1 \mathrm{~m}, \mathrm{SD}=46.60, n=51$; for the second and third litter young, mean $18.2 \mathrm{~m}$, $\mathrm{SD}=13.71, n=31$; Mann-Whitney $U$-test, $Z=-3.34$, $P=0.001$ ). Dispersing young that moved more than $50 \mathrm{~m}$ were significantly older than philopatric ones in both sexes at mid-January (Mann-Whitney $U$-test, $P<0.05$ for both sexes; Table 1). These dispersers tended to be heavier than philopatric young at mid-January, although the difference was not significant (Mann-Whitney $U$-test, $P>0.1$ for both sexes; Table 1).

In summary, early fall-born females matured and dispersed during the fall. Thus, dispersing fall-born females were older and heavier than philopatric ones.

\section{Maternal family}

At mid-January of 1993, most fall-born young had an overlapping or adjoining home range with the mother, full sibling(s) and/or maternal half sibling(s), forming an maternal family $(n=18$, group-size range $=2-10$, mean $=5.44, \mathrm{SD}=2.31$; Fig. 2 ). In a few families, mothers had

Table 1. Age and body weight between philopatric and dispersing autumn-born individuals at mid-January of 1993 (mean \pm SD). Numbers in parentheses indicate the sample size.

\begin{tabular}{llccc}
\hline & & Philopatric & Dispersing & $Z^{\mathrm{a}}$ \\
\hline \multirow{2}{*}{ Age (days) } & Males & $71.51 \pm 14.382(49)$ & $83.43 \pm 3.259(7)$ & $-2.4824(P=0.015)$ \\
& Females & $69.31 \pm 11.349(36)$ & $82.33 \pm 6.541(12)$ & $-3.8363(P<0.001)$ \\
Body weight $(\mathrm{g})$ & Males & $27.47 \pm 3.342(49)$ & $29.29 \pm 3.426(7)$ & $-1.1803(P=0.244)$ \\
& Females & $25.53 \pm 2.670(36)$ & $27.25 \pm 3.858(12)$ & $-1.5626(P=0.122)$ \\
\hline
\end{tabular}

aMann-Whitney $U$-test. 
already died by late December of 1992 . The boundaries of maternal families were apparent, and rarely overlapped between neighboring families (Fig. 2). Spatial association between a father and the offspring was observed only in two maternal families, but most families did not include any male founders since most male founders shifted their home ranges or died by the end of the fall breeding season. Sex ratio of the maternal families ranged between 0.17 and $1.0($ mean $=0.52, \mathrm{SD}=0.24)$. Sex ratio of the pooled data among these maternal families did not differ from $0.5\left(\chi^{2}=0.040, P=0.920\right)$.

Only two maternal families included an unrelated disperser (i.e. a female and a male, respectively) in midJanuary (Fig. 2A). For one of the families, the mother and the unrelated female disperser had separate home ranges while being reproductively active. For the other, the mother had already died before the unrelated male joined.

\section{Mixed lineage group}

Individuals from several maternal lineages had an overlapping or adjoining home range to each other, forming mixed lineage groups during the winter (Fig. 2A, B). Three mixed lineage groups were observed. The largest mixed-lineage group consisted of a male founder, two philopatric unrelated young (a female and a male), two philopatric litter-mate pairs, and three dispersers (two males and a female) of which dispersal distances were over $80 \mathrm{~m}$ at mid-January of 1993 . Other mixed lineage groups consisted of male founder(s) and unrelated disperser(s). Sex ratio of the mixed lineage groups ranged between 0.29 and 0.83 (mean $=0.60, \mathrm{SD}=0.21$ ).

Four fall-born females and one female founder, which was reproductively active but failed to reproduce in the fall, did not make a distinct group, living solitarily or spatially associating with only a male (Fig. 2A).

\section{Winter survival}

The population decreased from 124 to 51 during winter (from mid-January of 1993 to early April). Survival rate during this period was slightly higher for females than males $(36.5 \%=23 / 63$ for males, $45.9 \%=28 / 61$ for females; Fisher's exact test, $P=0.189$ ).

Eleven maternal families and two mixed lineage groups were observed in late March at the similar position as observed at January (Fig. 2B). These groups decreased in number during the winter (range $=2-7$; mean $=3.85$, $\mathrm{SD}=1.52$ ). Movements of voles were rare during the winter. Two fall-born females moved from a maternal family which disappeared to the neighboring mixed lineage group. Only one solitary-living female was observed at late March (Fig. 2B).

Winter survival of fall-born individuals in maternal
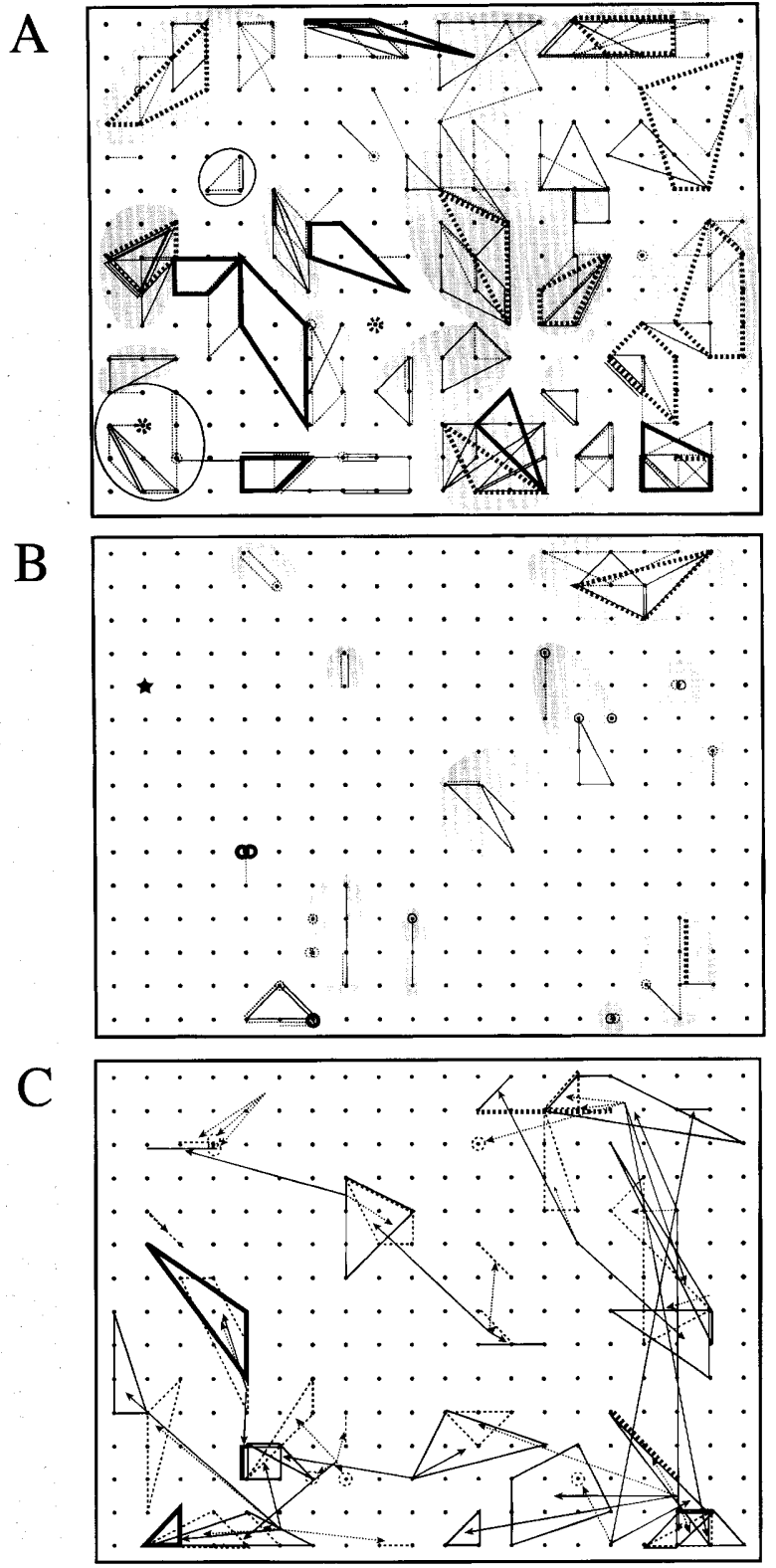

Fig. 2. Minimum boundary home ranges at mid-January (A), late March (B) and late April 1993 (C). Bold smooth and dotted lines represent the home range of male founders and that of female founders, respectively. Thin smooth and dotted lines represent the home range of fall-born males and that of fall-born females, respectively. Maternal families without unrelated individuals are indicated by shaded area. Maternal families with unrelated individuals are enclosed with a smooth ellipse. The trapping point of the female which overwintered solitarily is shown by a star (B). Arrows with a thin line and those with a dotted line show male movement and female movement from the estimated wintering site, respectively (C). Dots represent stations at $10 \mathrm{~m}$ interval. 
families was not affected by the presence of mother in mid-January $(41.9 \%=26 / 62$ for groups with mother, $61.9 \%=13 / 21$ for groups without mother; Fisher's exact test, $P=0.091$ ), in which two females that changed groups were excluded from the analysis. The group size in midJanuary had also no effects on survival rate in winter (Kendall correlation coefficient $=0.037, P=0.838, n=20$ ), in which one group which was dissolved due to individuals leaving the group, was excluded from the analysis. Among families with two or more litters, survival rate of fall-born voles from the first litters $(54.2 \%=26 / 48)$ was higher than that from the second or third litters (20.0\%=6/30; Fisher's exact test, $P=0.003$ ). Surviving males were significantly heavier than those that disappeared; such a difference was not observed in females (Table 2). Among fall-born voles from the first litters, winter survival rate for philopatric voles was significantly higher than that for dispersers $(63.0 \%=34 / 54$ for philopatric voles, $33.3 \%=6 / 18$ for dispersing ones; Fisher's exact test, $P=0.028$; Fig. 1 ).

Most of the fall-born voles that overwintered gained weight during the winter (from mid-January to midMarch); mean body mass (SD, sample size) increased from

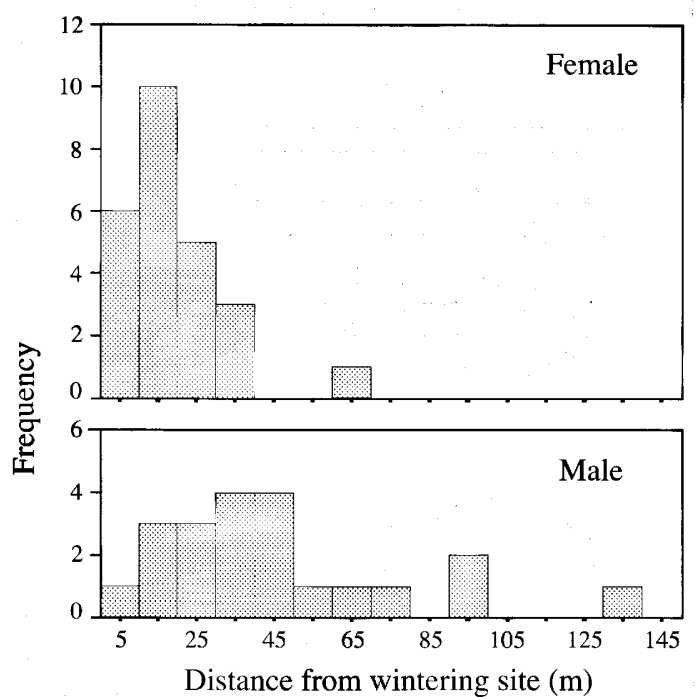

Fig. 3. Movement distance from the estimated wintering site to the breeding site at late April 1993.
$29.4 \mathrm{~g}(2.412, n=20)$ to $34.3 \mathrm{~g}(3.671, n=18)$ for males and from $26.1 \mathrm{~g}(2.405, n=26)$ to $29.1 \mathrm{~g}(3.301, n=24)$ for females (two males and two females could not be weighted in the mid-March). The mean growth rate of body mass was not different between the sexes $(16.7 \%$ for males and $11.5 \%$ for females; Mann-Whitney $U$-test, $Z=-1.14$, $P=0.258$ ).

\section{Dissolving wintering groups}

The spatial association among individuals was dissolved quickly after the onset of spring reproduction (Fig. 2C). By late April (19-21 April 1993), all but one overwintered fall-born females began to breed within $40 \mathrm{~m}$ from the wintering site (mean movement distance $21.0 \mathrm{~m}, \mathrm{SD}=$ 12.09, $n=23$; Figs. $2 \mathrm{C}$ and 3 ), and thus, maternal relatives formed kin clusters. Fall-born males, on the other hand, moved greatly in spring (mean movement distance $=56.6$ $\mathrm{m}, \mathrm{SD}=38.38, n=17$; Figs. $2 \mathrm{C}$ and 3 ). Movement distances from the wintering site to the first breeding site at late April differed significantly between the sexes (Mann-Whitney $U$-test, $Z=-4.01, P=0.0001$ ).

\section{Discussion}

This study revealed kinship among spatially associating individuals during winter in an enclosed population of the gray-sided vole. Maternal relatives of both sexes formed an apparent group (a maternal family) throughout winter, although a few families included unrelated individuals. Dispersers also formed mixed lineage groups irrespective of their kinship or sexes. Survival rate of fallborn voles from earlier litters was higher that from later ones. The clear relationship was found among dispersal pattern, reproduction and survival in fall-born females; many immature females stayed at their natal site and survived the winter, whereas most reproductively active females dispersed from their natal site in the fall and died during the winter. The maternal families broke up quickly after the onset of spring reproduction. Most females established a territory near their wintering sites, whereas males dispersed further. Thus, maternal families brought about female kin clusters in spring.

Table 2. Body weight (g) at mid-January of 1993 in the voles that survived the winter and in the voles that did not (mean \pm SD). Numbers in parentheses indicate the sample size.

\begin{tabular}{lccc}
\hline & Survived & Died & $Z^{\mathrm{a}}$ \\
\hline Males & $29.35 \pm 2.412(20)$ & $26.80 \pm 3.559(35)$ & $-2.9751(P=0.003)$ \\
Females & $26.12 \pm 2.405(26)$ & $25.77 \pm 3.741(22)$ & $-0.6427(P=0.535)$ \\
\hline
\end{tabular}

aMann-Whitney $U$-test. 
In microtine rodents, reproductive females may keep their territory (exclusive home rage) from each other through aggressive interactions during the breeding season in order to protect resources, e.g. food (Ostfeld 1985, 1990) and/or own juveniles from infanticide by others (Wolff 1993). Such aggressiveness may, however, reduce after the breeding season and females become tolerant to others. For example, meadow voles (Microtus pennsylvanicus) formed mixed lineage groups by late winter (Madison et al. 1984; Madison and McShea 1987) and aggressive behaviors were rarely observed in winter (McShea 1990). In our gray-sided vole population, mothers also seem to be tolerant toward unrelated females during reproductively inactive periods, because a maternal family shared a space with an unrelated female after fall breeding, despite the presence of her offspring. This change from aggressive interaction to amicable one may allow unrelated neighbors of both sexes to form a mixed lineage group after fall breeding.

Survival rates are usually higher during winter than during the breeding season in Clethrionomys species, despite limited or, at least, unrenewable food supply during winter (Petrusewicz et al. 1971; Bujalska 1975; Dewa 1975; Viitala 1977). The relatively low winter mortality could be related to the huddling and the change in social system from territorial during the breeding season to aggregation during winter (Kalela 1957; Madison 1984; West and Dublin 1984). Such a change in the social organization may help to lower the energy expenditure (Grodziński et al. 1977; Wolff and Lidicker 1981; Petrusewicz et al. 1983; Hayes et al. 1992). In the present study, almost all survivors maintained a group throughout the winter, and only one vole was solitarily in winter. In addition, winter survival rate for philopatric voles was higher than that for dispersers. Thus, winter group formation appeared to be beneficial to survival. Berteaux et al. (1996), however, did not find any physical benefit of winter aggregations; group size has no effect on physical conditions of voles in their field experiment. Further field experiments controlling other possible benefits (e.g. decreasing predation or fostering familiarity) are needed.

Dispersal pattern during fall was different from that during spring. Male-biased dispersal is known for the gray-sided vole (Saitoh 1995). Natal dispersal seems to occur voluntary at the beginning of reproduction in the gray-sided vole (Ims 1989, 1990; Ims and Andreassen 1991; Saitoh 1995), although adult males may influence the dispersal of male young (Ims 1987; Kawata 1989; Ims and Andreassen 1991). In the present study, however, sexual difference in dispersal tendencies was not observed in fall; most females that became reproductively active dispersed more than $50 \mathrm{~m}$, just like males during the breeding season (Fig. 1). Contrary to this, significant difference was observed between the sexes in the spring; almost all females held a territory within $40 \mathrm{~m}$ from the wintering site, whereas males dispersed further (Fig. 3).

This difference may have resulted from the difference in spatial distribution of dominant females between the seasons. During the fall, female founders held a territory uniformly within the enclosure. For fall-born, reproductively active females, there was not enough vacant space near their natal site in order to acquire their own breeding territories in the fall, whereas, in the spring, females were able to occupy easily a vacant space, where previous occupants had died, near the wintering site (Fig. 2). It is noteworthy that fall-born females that were reproductively inactive in the fall, stayed at their natal site, probably because they did not need their own territory.

Only a few studies refer to the social organization during winter, and it is also unknown about its effect on the survival and reproductive success in the subsequent seasons. Lambin and Krebs (1993) found in Townsend's voles ( $M$. townsendii) that the clustered dispersion of female relatives positively affect their reproductive success, i.e. weaning success of juveniles, in spring (see also Lambin and Yoccoz 1998). The social organization in spring is certainly formed during the winter. Lambin and Krebs (1991) assume that predation and other causes during winter decrease the cluster size of related individuals, which may create opportunities for settlement, and relatedness among voles is diluted by immigrants. They think that high relatedness in spring can be brought about by winter breeding. In this study the group size of maternal families decreased in winter. However, transference of individuals between wintering groups was rare and clusters of related females were observed in spring without winter breeding, although the enclosure, used in this study, excluded immigrants from the outside.

The present study suggests that the winter social organization of the gray-sided vole is essentially based on maternal families. Several unrelated females also overwintered together, and they established a territory in the proximity to the wintering site in spring. Such a mixed lineage group may foster familiarity among members in winter. Familiarity among neighbors can also positively affect the survival and/or reproductive success of individuals in microtines (Ylönen et al. 1995). In future studies, therefore, both effects of kinship and familiarity on survival and reproductive success should be considered. Furthermore, the present findings that immature fall-born females stayed at their natal site and survived the winter, whereas most reproductively active fall-born females dispersed from their natal site in the fall and died during the winter, may be one of the keys to understand density-dependent decline of vole populations in winter (Stenseth et al. 1998; Yoccoz et al. 1998). Since the breeding season is shortened in high density populations (Fujimaki 1969; Abe 1976), the proportion of fall-borns may be comparatively 
small during peak years. The process in which the structure of wintering populations is formed may vary depending on fall density.

Although more than a decade have gone since the importance of winter ecology was emphasized in small mammals by Merritt (1984), studies in this field of population ecology are still biased towards events during the summer season (Ishibashi et al. 1998). We hope that this study will stimulate further work on social organization during winter in fluctuating populations of microtine rodents.

Acknowledgments: We are grateful to M. Kawashima and A. Unno for their assistance of the field study. We are also indebted to Nils Chr. Stenseth for his valuable comments on earlier versions of this paper. Xavier Lambin and Nigel G. Yoccoz are thanked for their valuable comments. Y. I. was supported by the JSPS Fellowships for Japanese Junior Scientists.

\section{References}

Abe, H. (1976) Population structure and reproductive activity of Clethrionomys rufocanus bedfordiae (Thomas) in a wind shelterbelt of the Ishikari plain, Hokkaido. Journal of the Mammalogical Society of Japan 7: 17-30 (in Japanese with English summary).

Berteaux, D., J-M. Bergeron, D. W. Thomas and H. Lapierre (1996) Solitude versus gregariousness: do physical benefits drive the choice in overwintering meadow voles? Oikos 76: 330-336.

Bjørnstad, O. N., S. Champely, N. C. Stenseth and T. Saitoh (1996) Cyclicity and stability of grey-sided voles, Clethrionomys rufocanus, of Hokkaido: spectral and principal components analyses. Proceedings of the Royal Society of London B 351: 867-875.

Bjørnstad, O. N., N. C. Stenseth, T. Saitoh and O. C. Lingjærde (1998) Mapping the regional transition to cyclicity in Clethrionomys rufocanus: spectral densities and functional data analysis. Researches on Population Ecology 40: 77-84.

Boonstra, R., C. J. Krebs, M. S. Gaines, M. L. Johnson and I. T. M. Craine (1987) Natal philopatry and breeding systems in voles (Microtus spp.). Journal of Animal Ecology 56: 655-673.

Bujalska, G. (1975) Reproduction and mortality of bank voles and the changes in the size of an island population. Acta Theriologica 20: $41-56$.

Dewa, H. (1975) Seasonal variation of daily activity rhythms in snow season. Research Bulletin of College Experimental Forests Hokkaido University 22: 105-120 (in Japanese with English summary).

Fujimaki, Y. (1969) The fluctuations in the number of small rodents. Bulletin of the Hokkaido Forest Experiment Station 7: 62-77 (in Japanese with English summary).

Getz, L. L., B. McGuire, T. Pizzuto, J. E. Hofmann and B. Frase (1993) Social organization of the prairie vole (Microtus ochrogaster). Journal of Mammalogy 74: 44-58.

Grodziński, W., M. Makomaska, R. Tertil and J. Weiner (1977) Bioenergetics and total impact of vole populations. Oikos 29: 494510.

Hayes, J. P., J. R. Speakman and P. A. Racey (1992) The contributions of local heating and reducing exposed surface area to the energetic benefits of huddling by short-tailed field voles (Microtus agrestis). Physiological Zoology 65: 742-762.

Hayne, D. W. (1949) Calculation of size of home range. Journal of Mammalogy 30: 1-18.
Ims, R. A. (1987) Responses in spatial organization and behaviour to manipulations of the food resource in the vole Clethrionomys rufocanus. Journal of Animal Ecology 56: 585-596.

Ims, R. A. (1989) Kinship and origin effects on dispersal and space sharing in Clethrionomys rufocanus. Ecology 70: 607-616.

Ims, R. A. (1990) Determinants of natal dispersal and space use in grey-sided voles, Clethrionomys rufocanus: a combined field and laboratory experiment. Oikos 57: 106-113.

Ims, R. A. and H. P. Andreassen (1991) Does kinship influence space use and dispersal in male grey-sided voles? Oikos 62: 216220.

Ishibashi, Y., T. Saitoh, S. Abe and M. C. Yoshida (1995) Polymorphic microsatellite DNA markers in the grey red-backed vole Clethrionomys rufocanus bedfordiae. Molecular Ecology 4: 127128.

Ishibashi, Y., T. Saitoh, S. Abe and M. C. Yoshida (1997) Sexrelated spatial kin structure in a spring population of grey-sided voles Clethrionomys rufocanus as revealed by mitochondrial and microsatellite DNA analyses. Molecular Ecology 6: 63-71.

Ishibashi, Y., T. Saitoh and M. Kawata (1998) Social organization of the vole Clethrionomys rufocanus and its demographic and genetic consequences: a review. Researches on Population Ecology 40: $39-50$.

Kalela, O. (1957) Regulation of reproduction rate in subarctic populations of the vole Clethrionomys rufocanus (Sund.). Annales Academiae Scientiarum Fennicae, Series A IV, Biologica 34: 1-60.

Kawata, M. (1987) The effect of kinship on spacing among female red-backed voles, Clethrionomys rufocanus bedfordiae. Oecologia 72: 115-122.

Kawata, M. (1989) Growth and dispersal timing in male red-backed voles Clethrionomys rufocanus bedfordiae. Oikos 54: 220-226.

Lambin, X. and C. J. Krebs (1991) Can changes in female relatedness influence microtine population dynamics? Oikos 61: 126-132.

Lambin, X. and C. J. Krebs (1993) Influence of female relatedness on the demography of Townsend's vole populations in spring. Journal of Animal Ecology 62: 536-550.

Lambin, X. and N. G. Yoccoz (1998) The impact of population kin-structure on nestling survival in Townsend's voles, Microtus townsendii. Journal of Animal Ecology 67: 1-16.

Madison, D. M. (1984) Group nesting and its ecological and evolutionary significance in overwintering microtine rodents. pp. 267274. In J. F. Merritt (ed.) Winter ecology of small mammals. Carnegie Museum of Natural History, Pittsburgh.

Madison, D. M. and W. J. McShea (1987) Seasonal changes in reproductive tolerance, spacing, and social organization in meadow voles: a microtine model. American Zoologist 27: 899-908.

Madison, D. M., R. W. FitzGerald and W. J. McShea (1984) Dynamics of social nesting in overwintering meadow voles (Microtus pennsylvanicus): possible consequences for population cycling. Behavioral Ecology and Sociobiology 15: 9-17.

Mappes, T., H. Ylönen and J. Viitala (1995) Higher reproductive success among kin groups of bank voles (Clethrionomys glareolus). Ecology 76: 1276-1282.

Merritt, J. F. (ed.) (1984) Winter ecology of small mammals. Special Publication of Carnegie Museum of Natural History, Pittsburgh.

McGuire, B. and L. L. Getz (1995) Communal nesting in prairie voles (Microtus ochrogaster): an evaluation of costs and benefits based on patterns of dispersal and settlement. Canadian Journal of Zoology 73: 383-391.

McShea, W. J. (1990) Social tolerance and proximate mechanisms of dispersal among winter groups of meadow voles, Microtus pennsylvanicus. Animal Behaviour 39: 346-351.

Ostfeld, R. S. (1985) Limiting resources and territoriality in micro- 
tine rodents. American Naturalist 126: 1-15.

Ostfeld, R. S. (1990) The ecology of territoriality in small mammals. Trends in Ecology and Evolution 5: 411-415.

Petrusewicz, K., G. Bujalska, R. Andrzejewski and J. Gliwicz (1971) Productivity processes in an island population of Clethrionomys glareolus. Annales Zoologici Fennici 8: 127-132.

Petrusewicz, K., A. Górecki, W. Grodziński and J. Kozlowski (1983) Productivity and energetics. Acta Theriologica 28 Supplement 1: 173-205.

Saitoh, T. (1987) A time series and geographical analysis of population dynamics of the red-backed vole in Hokkaido, Japan. Oecologia 73: 382-388.

Saitoh, T. (1989) Communal nesting and spatial structure in an early spring population of the grey red-backed vole, Clethrionomys rufocanus bedfordiae. Journal of the Mammalogical Society of Japan 14: 27-41.

Saitoh, T. (1995) Sexual differences in natal dispersal and philopatry of the grey-sided vole. Researches on Population Ecology 37: 4957.

Saitoh, T., O. N. Bjørnstad and N. C. Stenseth (1998a) Densitydependence in voles and mice: a comparative study. Ecology (in press).

Saitoh, T., N. C. Stenseth and O. N. Bjørnstad (1998b) The population dynamics of the vole, Clethrionomys rufocanus, in Hokkaido. Researches on Population Ecology 40: 61-76.

Salvioni, M. and W. Z. Lidicker, Jr. (1995) Social organization and space use in California voles: seasonal, sexual, and age-specific strategies. Oecologia 101: 426-438.

Sambrook, J., E. F. Fritsch and T. Maniatis (1989) Molecular cloning: a laboratory manual, 2nd edn. Cold Spring Harbor Laboratory Press, New York.

Sera, W.E. and M.S. Gaines (1994) The effect of relatedness on spacing behavior and fitness of female prairie voles. Ecology 75: $1560-1566$.

SPSS Inc. (1995) SPSS for Windows. Release 6.1.3. SPSS Inc., Chicago.

Stenseth, N. C., O. N. Bjørnstad and T. Saitoh (1996) A gradient from stable to cyclic populations of Clethrionomys rufocanus in
Hokkaido, Japan. Proceedings of the Royal Society of London B 263: $1117-1126$.

Stenseth, N. C., O. N. Bjørnstad and T. Saitoh (1998) Seasonal forcing on the dynamics of Clethrionomys rufocanus: modeling geographic gradients in population dynamics. Researches on Population Ecology 40: 85-95.

Stickel, F. (1954) A comparison of certain methods of measuring ranges of small mammals. Journal of Mammalogy 35: 1-15.

Viitala, J. (1977) Social organization in cyclic subarctic populations of the voles Clethrionomys rufocanus (Sund.) and Microtus agrestis (L.). Annales Zoologici Fennici 14: 53-93.

West, S. D. and H. T. Dublin (1984) Behavioral strategies of small mammals under winter conditions: solitary or social? pp. 293-298. In J. F. Merritt (ed.) Winter ecology of small mammals. Carnegie Museum of Natural History, Pittsburgh.

Wolff, J. O. (1985) Behavior. pp. 340-372. In R. H. Tamarin (ed.) Biology of new world Microtus. The American Society of Mammalogists, Special Publication No. 8.

Wolff, J.O. (1993) Why are female small mammals territorial? Oikos 68: 364-370.

Wolff, J. O. (1995) Friends and strangers in vole population cycles. Oikos 73: 411-414.

Wolff, J. O. and W. Z. Lidicker, Jr. (1981) Communal winter nesting and food sharing in taiga voles. Behavioral Ecology and Sociobiology 9: 237-240.

Ylönen, H., T. Mappes and J. Viitala (1990) Different demography of friends and strangers: an experiment on the impact of kinship and familiarity in Clethrionomys glareolus. Oecologia 83: 333-337.

Ylönen, H., J. Pusenius and J. Viitala (1995) Impact of kinship and familiarity on the annual social organization and population dynamics of Clethrionomys and Microtus voles. Annales Zoologici Fennici 32: 225-232.

Yoccoz, N. G., K. Nakata, N. C. Stenseth and T. Saitoh (1998) The demography of Clethrionomys rufocanus: from mathematical and statistical models to further field studies. Researches on Population Ecology 40: 107-121.

Received 15 April 1998; Accepted 30 May 1998 